8. Lemière, Catherine, et al. Airway inflammation assessed by invasive and noninvasive means in severe asthma: eosinophilic and noneosinophilic phenotypes. Journal of Allergy and Clinical Immunology. 2006. P. 1033-1039.

9. Juniper EF, Guyatt GH, Feeny DH, Ferrie PJ, Griffith LE, Townsend M. Measuring quality of life in children with asthma. Qual Life Res. 1996. № 5. P. 35-46.

10. Michelle Gonçalves de Souza Tavares, Márcia Margaret Menezes Pizzichini, Leila John Marques Steidle, Nazaré Otília Nazário, Cristiane Cinara Rocha, Maíra Chiaradia Perraro, Emílio Pizzichini. The Asthma Control Scoring System: Translation and cross-cultural adaptation for use in Brazil. J Bras Pneumol. 2010. № 36(6). P. 683-692.

11. Montalbano L, Ferrante G, Montella S, et al. Relationship between quality of life and behavioural disorders in children with persistent asthma: a Multiple Indicators Multiple Causes (MIMIC) model. Sci Rep. 2020; №10(1) P. 6957. Published 2020 Apr 24.

12. Brand PL, Mäkelä MJ, Szefler SJ, Frischer T, Price D; ERS Task Force Monitoring Asthma in Children. Monitoring asthma in childhood: symptoms, exacerbations and quality of life. Eur Respir Rev. 2015. № 24(136). P. 187-193.

DOI https://doi.org/10.30525/978-9934-588-81-5-2.48

\title{
ЧИ МОЖНА ВИКОРИСТОВУВАТИ АНАМНЕСТИЧНІ ДАНІ I ВМІСТ ЗАГАЛЬНОГО ІGЕ ЯК ЧИННИКИ РИЗИКУ АТОПІЇ ПРИ БРОНХІАЛЬНІЙ АСТМІ У ШКОЛЯРІВ
}

\author{
Колоскова О. К. \\ доктор медичних наук, професор, \\ завідувач кафедри педіатрії та дитячих інфекиійних хвороб \\ Вищий державний навчальний заклад Украйни \\ «Буковинський державний медичний університет» \\ Мислицька Г. О. \\ аспірант кафедри педіатрії та дитячих інфекиійних хвороб \\ Вищий державний навчальний заклад Украӥни \\ «Буковинський державний медичний університет» \\ м. Чернівиі, Україна
}

Згідно сучасних поглядів, атопія характеризується продукцією специфічного IgE у відповідь на контакт з алергеном [1, с. 607-610], а шкірні уколочні алергопроби розглядаються як зручний тест по виявленню 
атопії [2, с. 355-359]. Так, про наявність атопічної реактивності свідчить щонайменше одна позитивна відповідь (із середнім діаметром пухиря $\geq 2$ мм) на алергени рослин, кліща домашнього пилу чи домашніх тварин (кота, собаки), за відсутності реакції на розчин від'ємного контролю (0,9\% натрію хлорид) та наявності відповіді на позитивний контроль (гістамін). Разом із тим, накопичено достатньо свідчень щодо фенотипової неоднорідності атопії та патофізіологічних механізмів іiі клінічної реалізації у вигляді, зокрема, астма-фенотипу.

У двох великих когортних дослідженнях (PASTURE i MAS), проведених в Європейських дослідницьких центрах, вивчалася фенотипова неоднорідність атопічної сенсибілізації у дітей протягом перших 6 років життя, та верифіковані доброякісний, симптоматичний та важкий атопічні фенотипи [3, с. 148-153]. Важкий атопічний фенотип становив $5 \%$, ще до формування бронхіальної гіперсприйнятливості у хворих він характеризувався зростанням співвідношення $\mathrm{Th}_{2} / \mathrm{Th}_{1}$, різким підвищення сенсибілізації до сезонних аероалергенів і це супроводжувалось високим вмістом IgE у сироватці крові. Разом із тим, надмірне вироблення IgE у сироватці крові було пов'язане з порушенням функції легенів та збільшенням ризику розвитку астми у $20 \%$ випадків.

В іншому дослідженні [4, с. 388-399] показано, що сенсибілізація $\operatorname{IgE}$ сприяе лише 38\% мультиморбідності астми, риніту та екземи, а моносенсибілізація та полісенсибілізація до аероалергенів представляють два різні фенотипи, причому полісенсибілізація асоціюється з мультиморбідністю алергічних захворювань та проявляється раніше, ніж фенотип моносенсибілізації. Встановлено, що фенотип важкої алергії, що характеризується полісенсибілізацією та мультиморбідністю алергічних захворювань, включає відносно більш стійкі симптоми, більш важку астму та вищі рівні загального та специфічного IgE.

Разом із тим, існує припущення, що загальний сироватковий $\operatorname{IgE}$ надає загальну оцінку алергічного компоненту при астмі [5, с. 271-277], і асоціюється з астмою незалежно від рівня специфічних IgE [6, c. 1880-1884].

Мета роботи. Вивчити анамнестичні особливості та зростання концентрації загального сироваткового igE як чинників ризику атопічного фенотипу бронхіальної астми у дітей шкільного віку.

Матеріал і методи. Для досягнення поставленої мети методом простої випадкової вибірки сформована когорта з 64 дітей шкільного віку, хворих на персистувальну бронхіальну астму (ПБА), які з приводу загострення захворювання одержували стаціонарне лікування в Обласній дитячій клінічній лікарні м. Чернівці. Першу (I) групу склали 38 дітей із атопічним фенотипом БА (обтяжений на атопічну патологію генеалогічний анамнез, тобто атопічний генотип, який реалізувався у вигляді 
щонайменше однією позитивною відповіддю у прік-тестах з небактеріальними алергенами) $[21,73,97]$. До II клінічної групи увійшло 26 пацієнтів із ПБА без ознак атопії. За основними клінічними характеристиками групи порівняння були співставимі.

Шкірну чутливість негайного типу до побутових, харчових, епідермальних та пилкових алергенів із вмістом 10000 PNU в 1 мл. (виробництво ТОВ „Імунолог», м. Вінниця, Україна) визначали методом внутрішньошкірних прік-тестів. Через 15 хвилин вимірювали середню величину папули та гіперемії за відповідними довгими вісями та перпендикулярами до них. Атопія визначалася як позитивний шкірний тест до одного чи декількох алергенів згідно нормативно-регламентуючих настанов [7].

Результати та обговорення. Розподіл обстежених хворих за статтю узгоджувався 3 даними літератури про додатковий ризик чоловічої статі як чинника наявності атопії [8, с. 625-631]. Так, стосовно атопії даний чинник мав наступні показники клініко-епідеміологічного ризику: $\mathrm{OR}=2,41$ (95\% CI 1.33-4.36), RR=1.59 (95\%CI 1.28-1.98), $\mathrm{AR}=0.22$.

Не спостерігали вірогідних відмінностей у структурі тяжкості захворювання. В обох групах спостереження переважали пацієнти з середньо тяжкою $(58,0 \pm 8,0 \%$ та $42,3 \pm 9,7 \%$ у I та II клінічних групах відповідно $(\mathrm{P} \phi>0,05)$ та тяжкою ПБА $(36,8 \pm 7,8 \%$ та $46,1 \pm 9,8 \%$ відповідно $(\mathrm{P} \phi>0,05)$.

Оцінка дебюту захворювання в групах спостереження показала, що серед обстежених дітей з атопією незначно переважала «астма раннього початку» (до 3-х років включно): у 42,10 \% проти чверті спостережень $(26,9 \%)$ при неатопічному астма-фенотипу (Р $\phi>0,05)$. Показники клініко-епідеміологічного ризику атопії за даного старту ПБА становили: $\mathrm{OR}=1,98(95 \% \mathrm{CI} 1.1-3.58), \mathrm{RR}=1.38$ (95\% CI 1.0-2.05), $\mathrm{AR}=0.17$.

Показано, що у 56,8 \% випадків у I групі траплялися ознаки поліморбідності ПБА з симптомами алергічного риніту та атопічного дерматиту, а у II клінічній групі - у 42,3 \% спостережень $(\mathrm{P} \phi>0,05)$ із відповідними показниками клініко-епідеміологічного ризику наявної атопії: $\mathrm{OR}=1,79$ (95\% CI 1.02-3.14), RR=1.34 (95\%CI 1.01-1.78), $\mathrm{AR}=0.15$.

Особливості сенсибілізації дітей I групи (за даними відповіді у пріктестах) дозволили встановити, що максимальний розмір папули у пробі 3 побутовими алергенами сягав $17,9 \pm 6,2$ мм, епідермальними $14,3 \pm 5,8$ мм, пилковими - 11,6 $\pm 6,3$ мм та харчовими $-10,0 \pm 5,3$ мм (в усіх випадках $\mathrm{Pt}>0,05$ ).

Обтяжений сімейний алергологічний анамнез реєструвався у $80,6 \%$ випадків у I групі та у 69,2 \% спостережень у II групі $(\mathrm{P} \phi>0,05)$ із відповідними показниками клініко-епідеміологічного ризику атопії: $\mathrm{OR}=1,85$ (95\% CI 1.0-3.55), RR=1.39 (95\%CI 1.18-1.69), $\mathrm{AR}=0.15$. 
Встановлено, що вміст загального $\operatorname{IgE~y~сироватці~крові~у~групах~}$ хворих перевищував популяційну норму здорових дітей (120 МО/мл), та у школярів із атопічною ПБА становив 701,3 $\pm 56,0 \mathrm{MO} /$ мл, а у II гру-

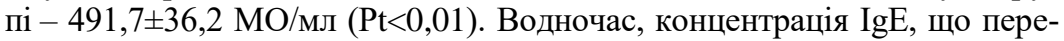
вищувала $125,0 \mathrm{MO} /$ мл реєструвалась у 82,6 \% випадків у дітей I групи та у $68,7 \%$ спостережень при неатопічній ПБА $(\mathrm{P} \phi>0,05)$ із показниками клініко-епідеміологічного ризику атопії: $\mathrm{OR}=2,16$ (95\% CI 1.11-4.22), $\mathrm{RR}=1.53$ (95\%CI 1.3-1.79), $\mathrm{AR}=0.19$.

У хворих на атопічну ПБА обтяжений сімейний алергологічний анамнез вирізнявся вірогідним позитивним кореляційним зв'язком 3 частотою нічних симптомів $(\mathrm{r}=0,55, \mathrm{p}<0,01)$, а наявність у родоводі хворих на ПБА родичів - 3 високою потребою у використанні швидкодіючих $\beta_{2}$-адреноміметиків $(\mathrm{r}=0,50, \mathrm{p}<0,05)$.

Висновки.

1. У школярів з атопічною персистувальною бронхіальною астмою найбільш істотною $є$ шкірна гіперчутливість до побутових алергенів (домашній пил, пух/перо подушки тощо), а найменшою сенсибілізація до харчових алергенів.

2. Обтяженість сімейного алергологічного анамнезу підвищує ризик атопічного фенотипу астми у 1,85 разу та корелює з недостатнім контролем над перебігом захворювання у вигляді нічних симптомів та потреби у швидкодопоміжній терапії.

3. Ризик атопічного фенотипу астми зростає у хлопчиків у 2,41 разу, при дебюту до 3-річного віку - у у 1,98 разу, за полліморбідності з іншими алергічними захворюваннями - у 1,79 разу.

4. Порівняно до неатопічного фенотипу астми, у дітей з атопією вміст загального сироваткового IgE $\epsilon$ вірогідно вищим, а за результатів більше 125,0 МО/мл ризик атопії зростає у 2,16 разу.

\section{Лiтература:}

1. Jarvis D, Burney P. The epidemiology of allergic disease. BMJ 1998. № 316. P. 607-610.

2. Oryszczyn M-P, Annesi I, Neukirch F, et al. Relationships of total IgE level, skin prick test response, and smoking habits. Ann Allergy 1991. № 67. P. 355-359.

3. Christina G. Kwong, Leonard B. Bacharier. Phenotypes of wheezing and asthma in preschool children. Curr Opin Allergy Clin Immunol. 2019. № 19(2). P. 148-153.

4. Anto JM, Bousquet J, Akdis M, et al. Mechanisms of the Development of Allergy (MeDALL): Introducing novel concepts in allergy phenotypes. J Allergy Clin Immunol. 2017; № 139(2). P. 388-99 
5. Burrows B, Martinez FD, Halonen M, et al. Association of asthma with serum IgE levels and skin-test reactivity to allergens. $N$ Engl J Med. 1989. № 320. P. 271-277.

6. Sunyer J, Antó JM, Castellsagué J, et al. Total serum IgE is associated with asthma independently of specific IgE levels. Eur Respir. J 1996. № 9. P. 1880-1884.

7. Наказ Міністерства охорони здоров'я України від 02.04.02 №_127/18/ Інструкція про порядок проведення специфічної діагностики та імунотерапії алергічних захворювань.

8. B. Leynaert, J. Sunyer, R. Garcia-Esteban et al. Gender differences in prevalence, diagnosis and incidence of allergic and non-allergic asthma: a population-based cohort. Thorax. 2012. № 67. P. 625-631

DOI https://doi.org/10.30525/978-9934-588-81-5-2.49

\title{
ОСОБЛИВОСТІ УРАЖЕННЯ ШКІРИ У ДІТЕЙ НА ТЛІ ХРОНІЧНОГО ЗАКРЕПУ
}

\author{
Конопліцька А. П. \\ кандидат медичних наук, \\ доиент кафедри педіатрії № 1
}

Вінницький національний медичний університет імені М. І. Пирогова

Антонець B. А.

кандидат медичних наук,

доиент кафедри педіатрії № 1

Вінницький національний медичний університет імені М. І. Пирогова

\section{Чорнопищук Н. П.}

асистент кафедри педіатрії № 1

Вінницький національний медичний університет імені М. І. Пирогова

Мазур О. Г.

кандидат медичних наук,

асистент кафедри педіатрії № 1

Вінницький національний медичний університет імені М. I. Пирогова

\section{Плахіна О. С.}

студентка V курсу

Вінницький національний медичний університет імені М. I. Пирогова м. Вінниця, Украӥна

Актуальність. Закрепи є однією з причин звернення до дитячих гастроентерологів, що становить до 25\% звернень до спеціаліста [2]. Подеку- 